\title{
KEGAGALAN PEMBUKAAN PENGUNCI STERN RAMP PADA MV. DREAM DIAMOND
}

\author{
Dwi Antoro
}

\author{
Dosen Program Studi Nautika PIP Semarang
}

\begin{abstract}
ABSTRAK
Pengunci stern ramp door adalah salah satu alat yang perannya sangat penting untuk kapal Ro-Ro yang berfungsi untuk merapatkan stern ramp door sehingga menjadi kedap air serta menahan ramp door dari goncangan apabila terjadi cuaca buruk. Pengunci stern ramp door memiliki sistem kerja yang sederhana tetapi apabila terjadi kegagalan pada pembukaan penguncistern ramp door dampak yang ditimbulkan sangat besar salah satunya adalah tertundanya proses bongkar ataupun muat.

Penelitian ini menggunakan analisa fishbone dan USG. Dalam menentukan penyebabpenyebab yang menyebabkan kegagalan pada pembukaan pengunci stern ramp peneliti menggunakan metode fishbone. Dan untuk menentukan prioritas masalah untuk diselesaikan peneliti menggunakan metode USG.

Hasil penelitian menunjukkan bahwa penyebab terjadinya kegagalan pembukaan pengunci stern ramp pada MV. Dream Diamond yaitu tidak melakukan pengecekan sebelum digunakan. Upaya yang dilakukan untuk mencegah kegagalan pada pembukaan pengunci stern ramp yaitu dengan melakukan pengecekan sebelum menggunakan pengunci stern ramp serta pemberian education tentang pengoperasian pengunci stern ramp juga harus dilakukan terhadap seluruh crew terutama crew baru tentang pengoperasian pengunci stern ramp sesuai prosedur yang ada.
\end{abstract}

\section{Kata kunci: pengunci stern ramp door}

\section{PENDAHULUAN}

Korea Selatan dan Jepang merupakan negara maju di kawasan Asia yang berusaha meningkatkan perekonomian di sektor perdagangan ekspor. Salah satu barang yang diekspor adalah mobil. Untuk mendistribusikan mobil dalam jumlah besar dengan biaya yang murah, cepat serta aman perusahan menggunakan alat transportasi kapal dengan jenis $R o-R o$.

Kapal Ro-Ro pada tempat taruna melaksanakan praktek laut memiliki kapasitas \pm 4.400 unit mobil dan memiliki 2 buah pintu rampa. Pintu rampa merupakan pintu penghubung antara kapal dengan pelabuhan yang memiliki sistem kerja seperti jembatan. Untuk mengamankan pintu rampa dalam pelayaran, terdapat pengunci pintu rampa dengan sistim hidrolik. Pengunci tersebut terdapat di sisi luar dan dalam pintu rampa. Pengunci tersebut dikontrol melalui control box yang berada di sky deck. Crew kapal yang bertugas mengoperasikan control box yang berada di sky deck adalah bosun. Sebelum melakukan bongkar muat, terlebih dahulu bosun akan membuka pintu rampa yang menjadi akses utama dalam melakukan bongkar muat di atas kapal Ro-Ro. Akan tetapi terjadi kegagalan pembukaan pintu rampa dikarenakan pengunci hidraulik tidak dapat terbuka meskipun pada control box telah menyala indikator lampu pada posisi terbuka. Kegagalan pembukaan pengunci stern ramp menyebabkan keterlambatan bongkar muat pada kapal tersebut. 
Dwi Antoro

Berdasarkan latar belakang yang telah dikemukakan tersebut, maka terdapat beberapa permasalahan yang akan peneliti jadikan perumusan masalah dalam pembuatan penelitian, yang berkaitan dengan persiapan ruang muat serta masalah-masalah yang sering dihadapi diatas kapal adalah:

1. Apakah yang menyebabkan kegagalan pembukaan pengunci stern ramp pada MV. Dream Diamond?

2. Bagaimana cara menanggulangi kegagalan pembukaan pengunci stern ramp pada MV. Dream Diamond?

\section{KAJIAN PUSTAKA}

\section{A. Kajian Pustaka}

Analisa merupakan suatu cara membagi suatu subjek ke dalam komponen-komponen, artinya melepaskan, menanggalkan, menguraikan sesuatu yang terikat padu. (Minto Rahayu, 2012).

Kegagalan adalah suatu keadaan dimana sebuah mesin tidak dapt berfungsi seperti fungsi dasar dari mesin tersebut. (Sudjatmiko 19973:13).

Menurut Kamus Besar Bahasa Indonesia, pengunci berasal dari kata dasar kunci. Kunci pertama kali ditemukan 4.000 tahun lalu oleh seorang arkeolog di istana Khorsabad dekat dengan Niniwe (Irak). Kunci pertama kali terbuat dari kayu yang digunakan untuk mengamankan pintu. Kemudian seiring dengan dengan berjalannya waktu, para penemu pada abad 18 ke 19 meningkatkan tingkat keamanan pengunci.

Ramp door atau dalam bahasa Indonesia yaitu pintu rampa. Menurut Jokosiswoyo, S (2011) ramp door atau pintu rampa adalah pintu yang digunakan untuk memasukkan kendaraan ke dalam kapal Ro-Ro. Ramp door pada dasarnya berfungsi sebagai jembatan penghubung antara kapal dengan dermaga. Penggunaan ramp door pada kapal pengangkut kendaraan sangat penting karena merupakan akses utama dalam pelaksanaan bongkar muat.

Dari pengertian di atas dapat disimpulkan bahwa analisis kegagalan pembukaan pengunci stern ramp adalah suatu kegiatan untuk membagi permasalahan kegagalan pengoperasian menjadi komponen-komponen dan diuraikan antar bagian yang saling terikat untuk mendapatkan penyebabpenyebab kegagalan pembukaan pengunci stern ramp serta langkahlangkah untuk menanggulangi kegagalan pembukaan pengunci stern ramp.

B. Kerangka Pikir Penelitian

Berdasarkan penelitian yang dilakukan peneliti yaitu kegagalan pembukaan pengunci stern ramp pada MV. Dream Diamond dengan melakukan analisa hasil penelitian melalui observasi, wawancara, dokumentasi, dan studi pustaka yang kemudian hasil penelitian dimasukkan ke dalam analisis fishbone untuk mendapatkan faktor-faktor penyebab kegagalan pembukaan pengunci stern ramp dan kemudian menggunakan USG (Urgency, Seriously and Growth) untuk mendapatkan faktor penyebab utama. Berikut adalah gambaran kerangka pikir penelitian tersebut :

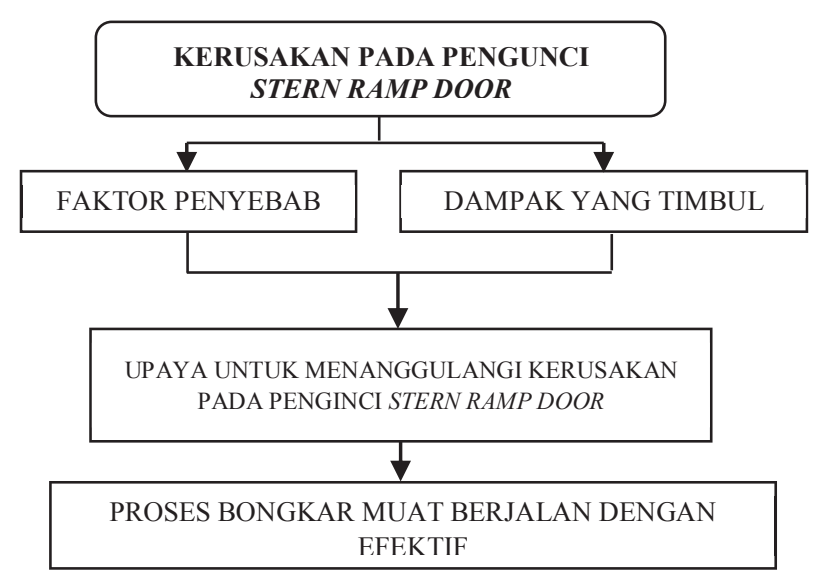

Gambar 1. Kerangka pikir penelitian 


\section{METODOLOGI}

\section{A. Metode Penelitian}

Metode pengumpulan data merupakan suatu bagian yang penting dalam penelitian. Berdasarkan referensi yang telah dibaca sebelumnya, penelitian ini menggunakan beberapa teknik pengumpulan data antara lain:

1. Metode Observasi (Pengamatan)

Observasi adalah cara pengumpulan data dengan cara melakukan pencatatan secara cermat dan sistematik. Dalam hal ini peneliti melakukan pengamatan pada stern ramp door di kapal MV. Dream Diamond tentang kegagalan pembukaan pengunci pada stern ramp door dari tanggal 10 Agustus 2016 sampai dengan tanggal 10 Agustus 2017.

2. Metode Wawancara

Wawancara digunakan sebagai pengumpulan data awal oleh peneliti untuk menemukan permasalahan yang akan diteliti. Wawancara digunakan juga untuk memberikan bukti dalam mencari pembahasan masalah. Dalam metode ini, peneliti menanyakan langsung kepada Kapten maupun Mualim tentang kegagalan pembukaan pengunci stern ramp door.

3. Studi Pustaka

Studi pustaka yang digunakan adalah pembahasan yang didasarkan dari catatan perwira. Studi pustaka juga merupakan suatu langkah untuk memperoleh informasi yang relevan dari suatu penelitian terdahulu yang harus dikerjakan dengan topik atau masalah yang akan atau sedang diteliti.

Dari metode yang dilakukan oleh peneliti diperoleh hasil berupa data sebagai berikut :
1. Data Primer

Data primer merupakan sumbersumber dasar yang merupakan bukti atau saksi utama dari kejadian yang lalu, dimana sumber primer adalah tempat atau gudang penyimpanan yang original dari data sejarah (Sugiyono, 2009: 245). Dalam hal ini peneliti mendapatkan data primer dengan observasi dan wawancara dengan narasumber yang berada di atas kapal pada saat peneliti melaksanakan penelitian di kapal MV. Dream Diamond.

2. Data Sekunder

Data sekunder adalah data yang memiliki suatu bentuk nyata dari suatu penelitian dan dapat diajukan acuan penelitian dan data sekunder diperoleh dari kajian-kajian pustaka yang diambil dari buku atau media internet. Untuk memperoleh data sekunder ini peneliti mengumpulkan data dari manual book, buku-buku yang ada di perpustakaan, dan datadata yang bersumber dari internet.

\section{B. Metode Analisis Data}

Metode yang akan digunakan oleh peneliti yaitu Fishbone (Tulang Ikan) dan USG (Urgency, Seriously, Growth). Berikut penjelasan dari metode Fishbone dan USG :

1. Fishbone ( Tulang Ikan)

Fishbone merupakan diagram tulang ikan karena pemecahan masalah dalam bentuk diagram tulang ikan juga disebut Cause and Effect Diagram atau Ishikawa Diagram. Diagram ini akan menunjukkan sebuah dampak atau akibat dari sebuah permasalahan, dengan berbagai penyebabnya. Efek atau akibat dituliskan sebagai moncong kepala. Sedangkan tulang ikan di isi oleh sebab-sebab sesuai dengan pendekatan permasalahannya. 
Dwi Antoro

2. Metode USG (Urgency, Seriously, Growth)

Alat pertama yang digunakan untuk menentukan permasalahan prioritas adalah dengan menggunakan Matriks USG Kepper dan Troge (1981) menyatakan pentingnya suatu maslah dibandingkan masalah lainnya dapat dilihat dari tiga aspek yaitu gawatnya masalah, mendesaknya masalah, serta perkembangan masalah. Pada penggunaan Matriks USG untuk menentukan suatu masalah yang prioritas, terdapat tiga faktor yang dipertimbangkan. Ketiga faktor tersebut adalah urgency, seriously dan growth. Berikut pengertian urgency, seriously dan growth, yaitu:

a) Urgency

Urgency mengenai seberapa mendesak isu tersebut harus dibahas dan dikaitkan dengan waktu yang tersedia serta seberapa keras tekanan terhadap waktu untuk memecahkan masalah yang menyebabkan isu tersebut.

b) Seriously

Seriously mengenai seberapa serius masalah atau isu tersebut harus dibahas dan dikaitkan dengan akibat yang timbul dengan penundaan pemecahan masalah yang menimbulkan isu atau masalah tersebut atau akibat yang dapat menimbulkan masalahmasalah lain jika masalah atau isu tersebut tidak dipecahkan.

c) Growth

Growth yaitu tentang kemungkinan isu atau permasalahan tersebut menjadi berkembang dan dikaitkan dengan kemungkinan masalah penyebab isu atau permasalahan semakin memburuk jika diabaikan.

Metode USG menggunakan teknik skoring dengan skala nilai skor 1-5 dan masalah dengan skor nilai tertinggi merupakan masalah prioritas.

\section{DISKUSI}

\section{A. Gambaran Umum Objek Penelitian}

Telah dijelaskan pada bab sebelumnya, peneliti melakukan penelitian pada kapal PCC (Pure Car Carrier) yaitu MV. Dream Diamond yang bertipekan dream series yang dapat memuat mobil hingga 4.400 unit. Kapal MV. Dream Diamond memliki data-data sebagai berikut :

Tabel 1 Ships's particular dari MV. Dream Diamond

\begin{tabular}{|c|c|c|c|}
\hline 1. & Ship's Name/Type & \multicolumn{2}{|c|}{ MV. Dream Diamond } \\
\hline 2. & Ship's Flag/Registry & \multicolumn{2}{|c|}{ Panama } \\
\hline 3. & Call Sign & \multicolumn{2}{|l|}{$3 E H Y 5$} \\
\hline 4. & Official No. & \multicolumn{2}{|l|}{$32488-07-B$} \\
\hline \multirow{3}{*}{5.} & \multirow{3}{*}{ Gross Tonnage } & $\begin{array}{l}\text { Internation } \\
\text { al }\end{array}$ & 41.662 \\
\hline & & Suez & 46.604 \\
\hline & & Japan & 25.335 \\
\hline 6. & $L O A / L B P$ & \multicolumn{2}{|c|}{$186.03 \mathrm{M} / 181.03 \mathrm{M}$} \\
\hline 7. & Breadth / Depth & \multicolumn{2}{|c|}{$28.20 \mathrm{M}$} \\
\hline 8. & Owner & \multicolumn{2}{|c|}{$\begin{array}{l}\text { Dynamic Jumping } \\
\text { Marine S.A }\end{array}$} \\
\hline 9. & Operator & \multicolumn{2}{|c|}{$\begin{array}{l}\text { CIDO SHIPPING CO. } \\
\text { Ltd }\end{array}$} \\
\hline 10 & Summer Draft & \multicolumn{2}{|c|}{$8.500 \mathrm{M}$} \\
\hline 11. & Light Ship & \multicolumn{2}{|l|}{$11.613 \mathrm{M}$} \\
\hline 12. & D.W.T & \multicolumn{2}{|l|}{15069} \\
\hline 13. & Depth Freeboard & \multicolumn{2}{|l|}{$29.43 M$} \\
\hline 14. & Main Engine & \multicolumn{2}{|c|}{ 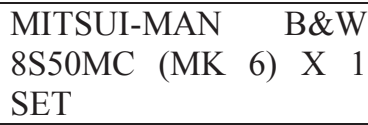 } \\
\hline 16. & Date of Built & \multicolumn{2}{|l|}{20 Jan 2007} \\
\hline 17. & Service Speed/Max & \multicolumn{2}{|l|}{ 19.2 Knot } \\
\hline
\end{tabular}

\section{B. Analisis Data}

Analisis masalah merupakan langkah awal untuk mencari jawaban sementara penyebab timbulnya masalah berdasarkan rumusan masalah yang diangkat peneliti, Melalui analisisanalisis didapatkan masalah-masalah yang pada akhirnya akan dibahas pada pembahasan masalah. 


\section{Analisa Fishbone}

Berdasarkan penelitian peneliti selama peneliti melakukan penelitian di kapal MV. Dream Diamond telah terjadi kegagalan pembukaan pada pengunci stern ramp. Peneliti melakukan pengamatan untuk menemukan faktor-faktor yang yang menjadi penyebab kegagalan pembukaan pada pengunci stern ramp. Faktor-faktor penyebab terjadinya kegagalan pembukaan pada pengunci stern ramp peneliti masukkan ke dalam fishbone diagram untuk disusun menyerupai tulang ikan dimana faktor-faktor penyebab kegagalan pada pembukaan pengunci stern ramp digambarkan sebagai penyebab dan kegagalan pada pengunci stern ramp sebagai kepala ikan atau akibat dari faktor-faktor yang ada. Penggunaan fishbone diagram yang digunakan peneliti untuk menggambarkan penyebab yang ada dan akibat atau kerusakan yang terjadi berfungsi untuk menjabarkan kendala-kendala yang terjadi di MV. Dream Diamond. Kendala-kendala tersebut meliputi:

a. Manusia atau Man;

b. Lingkungan atau Environtment;

c. Metode atau Methode;

d. Mesin atau Mechine.

Kendala-kendala tersebut peneliti gambarkan dalam fishbone diagram sebagai berikut :

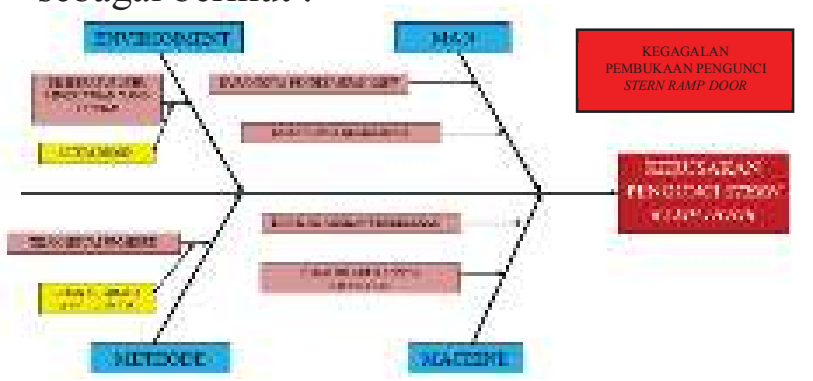

Gambar 2. Fishbone Analysis menyebabkan kegagalan pada pembukaan pengunci stern ramp MV. Dream Diamond adalah:

a. Man (Manusia)

1) Kurangnya pengetahuan crew Kurangnya pengetahuan crew kapal tentang pengoperasian pengunci stern ramp pada MV. Dream Diamond dikarenakan banyaknya crew kapal yang baru pertama kali bekerja dengan kapal berjenis Ro-Ro sehingga mengakibatkan minimnya pengetahuan crew kapal tentang pengoperasian di atas kapal Ro-Ro khususnya pada bagian pengunci stern ramp. Selain karena pertama kali bekerja pada kapal bertipe Ro-Ro, malasnya crew kapal untuk membaca buku panduan manual yang ada di kapal mengenai pengunci stern ramp menjadi penyebab kurangnya pengetahuan crew kapal mengenai pengunci stern ramp. Akibatnya pengoperasian pengunci stern ramp tidak sesuai dengan panduan yang terdapat pada manual book dan dapat membahayakan pengunci pada stern ramp bahkan dapat menyebabkan kerusakan.

2) Kurangnya Komunikasi

Kurangnya komunikasi antar crew dalam proses pengoperasian pembukaan pengunci stern ramp sangat berbahaya bagi kelancaran pengoperasian pembukaan ramp door. Komunikasi secara terus menerus ketika dalam proses pembukaan ramp door termasuk ketika mulai membuka pengunci stern ramp sangatlah vital karena kontrol box berada di sky deck sedangkan pengunci stern ramp 
Dwi Antoro

berada di main deck atau deck 5 sehingga apabila tidak terjadi komunikasi secara baik menyebabkan crew lain yang sedang mengoperasikan kontrol box di main deck tidak memahami atau tidak mengerti kondisi yang sedang terjadi.

\section{b. Methode (Metode)}

Pelaksanaan pembukaan pengunci stern ramp yang dilakukan tidak sesuai dengan prosedur yang terdapat pada buku panduan manual. Tidak terlaksananya pengoperasian pengunci stern ramp dikarenakan minimnya pengetahuan yang dimiliki crew kapal tentang pengoperasian pengunci stern ramp, minimnya pengetahuan crew kapal mengenai pengunci stern ramp karena sebagian besar crew kapal baru pertama kali bekerja di kapal dengan tipe Ro-Ro. Selain dari minimnya pengetahuan, tidak terlaksananya pengoperasian sesuai prosedur dikarenakan malasnya crew kapal untuk menambah pengetahuan dengan membaca buku panduan manual prosedur pengoperasian pengunci stern ramp.

Selain malasnya crew kapal dalam membaca buku panduan manual, sulitnya memahami buku panduan manual prosedur pengoperasian pengunci stern ramp dikarenakan buku tersebut berbahasa Inggris. Sedangkan kemampuan bahasa yang dimiliki crew kapal masih kurang baik. Akibatnya crew kapal melakukan pengoperasian pengunci stern ramp tidak sesuai dengan prosedur yang ada sehingga dapat menimbulkan potensi kegagalan pada pembukaan pengunci stern ramp. c. Machine (Mesin)

1) Tidak Dilakukan Pengecekan Pengecekan pada pengunci stern ramp sebelum melakukan bongkar muat merupakan hal yang sangat fatal. Pengecekan terhadap pengunci stern ramp bertujuan untuk memastikan apakah pengunci stern ramp dalam keadaan baik dan dapat dipergunakan atau tidak. Serta memastikan normalnya operasional dari pengunci stern ramp. Kurangnya pengalaman crew dan seringnya crew meremehkan hal-hal yang menjadi dasar pengoperasian menjadi salah satu penyebab permasalahan. Dalam permasalahan yang diamati oleh peneliti, permasalahan ini timbul pada pengunci stern ramp.

Crew kapal yang meremehkan tindakan dasar dalam pengoperasian yaitu tidak melakukan pengecekan sebelum mengoperasikan pengunci stern ramp menyebabkan tidak mengetahuinya kegagalan operasi dari salah satu bagian dari sistem pengunci stern ramp sehingga mengakibatkan gagalnya atau tidak dapat terbukanya pengunci stern ramp.

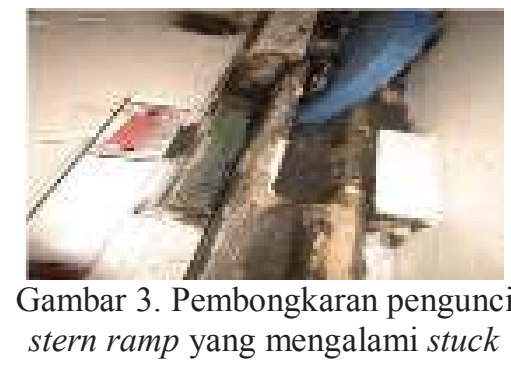

2) Tidak Dilakukannya Perawatan Berkala

Perawatan merupakan kegiatan untuk memperpanjang 
masa guna suatu benda begitu juga dengan pengunci stern ramp yang bekerja sebelum dan sesudah bongkar muat ataupun selama pintu stern ramp dalam keadaan tertutup juga harus mendapatkan perawatan. Pada dasarnya perawatan pada suatu alat atau suatu benda memerlukan beberapa kegiatan seperti :

a) Kegiatan pemeriksaan atau pengecekan;

b) Kegiatan memberi pelumas atau lubrication;

c) Kegiatan perbaikan atau repairing pada bagian yang rusak;

d) Kegiatan penggantian suku cadang atau spare part.

Perawatan terhadap suatu alat atau barang guna memperpanjang masa pemakaian atau umur suatu alat dapat dilakukan secara berkala. Perawatan berkala dilakukan sesuai dari periode waktu yang telah dicantumkan pada daftar perbaikan atau planned maintenence dan juga dapat dilihat dari manual book.

d. Temperatur suhu lingkungan yang rendah atau dingin

Cuaca yang dingin pada musim dingin dapat mengakibatkan menggumpalnya cairan hidrolik pada pengunci stern ramp. Pada dasarnya setiap cairan memiliki batasan terendah dan tertinggi, dimana pada batasan tertinggi maka cairan akan menjadi panas dan pada batasan terendah cairan akan menjadi beku. Sama halnya dengan cairan hidrolik yang memiliki batas panas dan batas dingin. Cairan hidrolik dapat bertahan hingga suhu 180 derajat farenheit. Sedangkan pada titik beku, cairan hidrolik dapat bertahan pada 10-15 derajat celcius di bawah suhu permulaan, untuk mengantisipasi terjadinya penyumbatan oleh cairan hidrolik yang membeku.

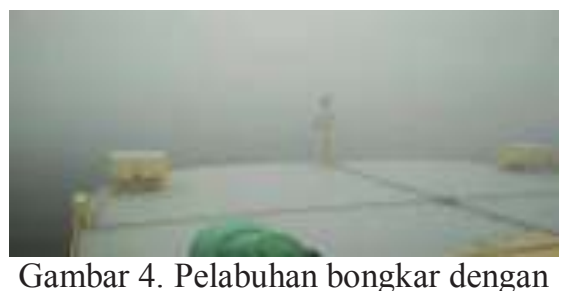
suhu yang rendah

Pada kapal MV. Dream Diamond dimana pada saat melakukan pembukaan pengunci stern ramp untuk melakukan operasi bongkar muat sedang terjadi musim dingin dengan suhu 2 derajat celcius, sehingga menyebabkan ciaran hidrolik yang terdapat pada pengunci stern ramp mengalami kegumpalan atau menjadi lebih kental. Akibatnya salah satu sisi pengunci stern ramp tidak dapat terbuka dan proses bongkar muat pun tertunda.

Setelah melakukan penelitian berdasarkan penyebab-penyebab atau faktor-faktor yang menyebabkan kegagalan pada pembukaan pengunci stern ramp. Maka dampak yang ditimbulkan dari kegagalan pada pembukaan pengunci stern ramp yaitu salah satunya adalah tertundanya kelangsungan proses bongkar muat. Tertundanya kelangsungan proses bongkar muat merupakan dampak dari kegagalan pembukaan pengunci pada stern ramp. Kerugian juga berdampak tidak hanya pada kapal namun juga dapat merugikan perusahaan. Karena pada dasarnya perusahaan memberikan perintah untuk kapal agar melakukan proses bongkar ataupun muat di suatu daerah atau 
Dwi Antoro

pelabuhan atas dasar bisnis. Dan biaya sandar kapal untuk bongkar dan muat telah diperhitungkan sebaik mungkin sesuai dengan waktu yang dibutuhkan.

Jika terjadi penundaan pada pelabuhan dengan tingkat keketatan inspection yang tidak terlalu ketat tentunya tidak akan begitu berimbas besar baik terhadap perusahaan ataupun crew kapal. Akan tetapi jika terjadi di pelabuhan dengan tingkat keketatan inspection yang tinggi tentunya akan menyebabkan masalah. Bahkan kapal tidak akan diijinkan melakukan perjalanan sebelum perusahaan datang dan memberikan keterangan serta memberikan pernyataan atau bahkan segera melakukan perbaikan terhadap kerusakan yang ada. Dan pada pelabuhan selanjutnya Master dan kepala kamar mesin dapat diturunkan atau diganti.

\section{Metode USG (Urgency, Seriously, Growth)}

Analisa data yang akan digunakan oleh peneliti untuk menganalisa rumusan masalah yang kedua yaitu menggunakan USG (Urgency, Seriously, Growth). Metode USG merupakan salah satu metode dengan mengurutkan prioritas masalah dengan metode nilai atau score. Proses untuk metode USG dilaksanakan dengan memperhatikan urgency dari masalah, keseriusan dari masalah yang dihadapi, dan kemungkinan berkembangnya masalah tersebut semakin besar. Dalam pembahasan masalah peneliti telah mengamati dan menyimpulkan masalah sebagai berikut : b. Kurangnya komunikasi pada saat pengoperasian;

c. Temperatur suhu lingkungan yang rendah;

d. Tidak dilakukan pengecekan sebelum pengoperasian;

e. Tidak dilakukannya perawatan secara berkala pada pengunci stern ramp;

f. Pengoperasian pada saat membuka atau menutup pengunci stern ramp tidak sesuai dengan prosedur yang ada.

Berikut adalah hasil sumber olah data yang peneliti buat untuk memprioritaskan masalah dengan menggunakan metode analisa data USG:

Tabel 2. Tabel Prioritas Masalah Dalam Metode

\begin{tabular}{|c|c|c|c|c|c|c|}
\hline \multicolumn{7}{|c|}{ USG } \\
\hline \multirow{2}{*}{ No } & \multirow{2}{*}{ MASALAH } & \multicolumn{4}{|c|}{ NILAI } & \multirow{2}{*}{ PRIORITAS } \\
\hline & & $\mathrm{U}$ & $\mathrm{S}$ & $\mathrm{G}$ & $\mathrm{T}$ & \\
\hline A. & $\begin{array}{l}\text { Kurangnya } \\
\text { pengetahuan crew } \\
\text { kapal mengenai } \\
\text { pengunci stern } \\
\text { ramp. }\end{array}$ & 1 & 2 & 2 & 5 & V \\
\hline B. & $\begin{array}{l}\text { Kurangnya } \\
\text { komunikasi pada } \\
\text { saat } \\
\text { pengoperasian. }\end{array}$ & 4 & 1 & 2 & 7 & IV \\
\hline C. & $\begin{array}{l}\text { Temperatur suhu } \\
\text { lingkungan yang } \\
\text { rendah. }\end{array}$ & - & 1 & 3 & 4 & VI \\
\hline D. & $\begin{array}{l}\text { Tidak dilakukan } \\
\text { pengecekan } \\
\text { sebelum } \\
\text { ngoperasian. }\end{array}$ & 4 & 5 & 2 & 11 & I \\
\hline E. & $\begin{array}{l}\text { Tidak } \\
\text { dilakukannya } \\
\text { perawatan secara } \\
\text { berkala pada } \\
\text { pengunci stern } \\
\text { ramp. }\end{array}$ & 3 & 3 & 3 & 9 & II \\
\hline F. & $\begin{array}{l}\text { Pengoperasian } \\
\text { pada saat } \\
\text { membuka atau } \\
\text { menutup pengunci } \\
\text { stern ramp tidak } \\
\text { sesuai dengan } \\
\text { prosedur yang } \\
\text { ada. }\end{array}$ & 3 & 3 & 2 & 8 & III \\
\hline
\end{tabular}


Pengertian :

U : Urgency yaitu masalah yang apabila tidak segera diatasi akan berakibat fatal dalam jangka pendek.

S : Seriously yaitu masalah yang apabila terlambat penanganan akan berdampak fatal terhadap kegiatan dan berpengaruh pada jangka panjang.

G : Growth yaitu permasalahan yang berpotensi akan tumbuh dan berkembang masalah baru dalam jangka panjang.

Tabel 3. Tabel Skala Penilaian Metode USG

\begin{tabular}{|c|c|}
\hline Skala & Penilaian \\
\hline 1 & Sangat Kurang \\
\hline 2 & Kurang \\
\hline 3 & Cukup \\
\hline 4 & Baik \\
\hline 5 & Sangat Baik \\
\hline
\end{tabular}

Dari tabel penilaian dengan cara USG tersebut maka diperoleh prioritas masalah berdasarkan tingkat bahaya suatu kejadian yang pernah dialami dan disimpulkan yaitu tidak dilakukan pengecekan sebelum pengoperasian. Pengecekan sebelum melakukan pengoperasian stern ramp sangatlah penting, pengecekan dilakukan terhadap komponen yang dapat dilihat secara visual dan pengecekan terhadap mesin hidrolik pengunci stern ramp. Pengecekan sebaiknya dilakukan sehari sebelum tiba di pelabuhan tujuan atau sehari sebelum menggunakan ramp door untuk bongkar muat. Pengecekan secara visual dilakukan dengan menggunakan alat indra, pengecekan dilakukan dengan ;

a. Memastikan tidak ada kebocoran dari jack hydraulic pengunci stern ramp; b. Memastikan pipa minyak atau pipa yang menghubungkan terhadap hidrolik pengunci stern ramp terpasang dengan baik;

c. Memastikan manual lock pin dapat terlepas dengan baik tanpa tersumbat apapun.

Selain melakukan pengecekan secara visual terhadap komponen yang dapat dicek menggunakan indra yang dimiliki manusia, pengecekan juga dilakukan terhadap mesin yang digunakan untuk mengoperasikan pengunci stern ramp. Pengecekan dilakukan dengan mengoperasikan pengunci stern ramp dengan cara membuka dan mengunci kembali pengunci stern ramp tanpa membuka ramp door. Pengecekan mesin hidrolik pengunci stern ramp dilakukan untuk memastikan pengunci stern ramp dapat beroperasi dengan baik. Pentingnya pengecekan terhadap pengunci stern ramp dikarenakan prosedur pengoperasian pengunci stern ramp pada saat musim panas dan dingin berbeda.

a. Pada musim panas

Pengoperasian pada saat membuka dan menutup pengunci stern ramp pada musim panas atau pada suhu normal dari daerah tropis dengan suhu $30^{\circ} \mathrm{C}$ memerlukan waktu beberapa menit saja untuk melakukan pengoperasian tersebut, dikarenakan suhu cairan pada hidrolik tidak mengalami kebekuan atau tidak mengental, seperti pada saat kapal berada pada musim dingin. Sehingga untuk melakukan pengoperasian alat untuk membuka pengunci stern ramp memerlukan pemanasan mesin sebentar saja. Akan tetapi jika pengoperasian tersebut tidak sesuai, maka resiko yang akan terjadi yaitu pengunci stern ramp 
Dwi Antoro

beroperasi tidak sesuai dengan prosedur dan mengakibatkan kerusakan sehingga pengunci pada stern ramp tidak dapat dibuka dan ramp door tidak dapat terbuka.

b. Pada musim dingin

Berbeda dengan pengoperasian pada saat membuka dan menutup pengunci stern ramp pada saat musim panas dengan suhu normal. Pada saat musim dingin memerlukan waktu yang cukup lama untuk melakukan operasi karena cairan hidrolik mengalami pembekuan dan menjadi kental. Oleh karena itu saat kapal memasuki daerah pelayaran yang sedang mengalami musim dingin dengan suhu di bawah $10^{\circ} \mathrm{C}$ bahkan sampai suhu di bawah $0^{\circ} \mathrm{C}$ yaitu suhu minus derajat, mesin pengunci stern ramp perlu melakukan pemanasan setiap harinya sekitar dua sampai empat jam. Supaya cairan pada pipa hidrolik tidak membeku sepenuhnya. Dan jika pemanasan terhadap mesin tidak dilakukan setiap harimaka pengoperasian tersebut akan membutuhkan waktu yang cukup lama untuk menaikkan suhu cairan hidrolik tersebut. Karena suhu minimum untuk cairan hidrolik agar dapat berjalan lancar yaitu $25^{\circ} \mathrm{C}$. Adapun jika hal-hal tersebut tidak dilaksanakan pada saat persiapan pembukaan pengunci stern ramp maka akan terjadi stuck dan pengunci stern ramp tidak dapat terbuka dan kemungkinan terburuknya yaitu terjadi kegagalan pada pembukaan pengunci stern ramp. Yang berdampak pada tertundanya proses bongkar dan memuat muatan. Dan akibatnya beberapa pihak akan mengalami kerugian, baik pihak perusahaan maupun pihak pemilik muatan.
Secara singkat peneliti akan menjelaskan cara penanggulangan terjadinya kegagalan pada pembukaan pengunci stern ramp. Karena merupakan tugas dan tanggung jawab pihak kapal apabila terjadi kegagalan pada pembukaan pengunci stern ramp. Hal-hal yang harus dilakukan untuk menanggulangi kerusakan pengunci stern ramp adalah :

a. Melakukan perawatan alat atau mesin secara berkala;

b. Pemberian pengarahan terhadap crew kapal tentang pengoperasian membuka dan mengunci pengunci stern ramp dengan baik dan benar;

c. Melakukan pengecekan secara berkala terutama sebelum melakukan pengoperasian.

Selain menjelaskan tentang penanggulangan kegagalan pada pembukaan pengunci stern ramp, peneliti juga melakukan observasi dan wawancara kepada perwira dan crew kapal tempat peneliti melakukan penelitian di kapal MV. Dream Diamond milik CIDO SHIPPING CO. Ltd selama satu tahun. Peneliti akan melakukan observasi dan wawancara penanggulangan terhadap kegagalan pada pembukaan pengunci stern ramp.

a. Kurangnya perawatan secara berkala

1) Menurut Hasil Wawancara Pada umumnya semua alat atau mesin selalu mendapatkan perawatan secara berkala agar dapat bekerja maksimal sebagaimana mestinya apabila suatu saat harus digunakan dengan segera. Akan tetapi jika sebuah mesin jarang mendapatkan perawatan bahkan tidak pernah mendapatkan perawatan maka ketika mesin tersebut harus bekerja dengan segera akan mendapatkan 
kendala pada beberapa aspek. Seperti yang telah peneliti lakukan penelitian tentang kerusakan pengunci stern ramp. Dimana pompa hidrolik terjadi stuck sehingga tidak dapat membuka pengunci stern ramp dikarenakan kurangnya perawatan pada alat atau mesin tersebut.

Dari penuturan Master, “Every machine must get service periodic, so we can know the little problem before become big problem. If we do maintenence periodic on time I think our machine will always in good condition because when you checking and find some mistake when you maintenence you can repair it immediately " yang artinya kurang lebih yaitu, "setiap mesin harus mendapatkan peratan secara berkala, jadi kita dapat mengetahui masalah kecil sebelum menjadi masalah besar. Jika kita melakukan perawatan berkala tepat waktu saya berpikir nasib kita akan selalu dalam keadaan baik karena ketika kamu melakukan pengecekan dan menemukan beberapa kerusakan ketika kamu melakukan perawatan kamu dapat melakukan perbaikan langsung". Salah satu penyebab rusaknya pompa hidrolik yang terjadi pada pengunci stern ramp adalah kurangnya perawatan yang berkala pada pompa hidrolik tersebut. Alat atau mesin yang sering dipakai membutuhkan perawatn yang serius agar alat atau mesin tersebut bekerja secara normal. Terlebih lagi jika alat tersebut tidak dirawat dengan baik akan tetapi dipergunakan secara terus menerus sehingga akan menimbulkan beberapa masalah.

2) Menurut Hasil Observasi

Dalam penelitian yang dilakukan peneliti di kapal MV. Dream Diamond, salah satu masalah yang timbul akibat kegagalan pada pembukaan pengunci stern ramp dikarenakan kurangnya perawatan mesin hidrolik yang berfungsi membuka dan menutup pengunci stern ramp. Mualim I bertanggung jawab penuh pada proses bongkar muat dan isi muatan, maka perlu memerintahkan crew kapal untuk selalu melakukan perawatan terhadap pengunci stern ramp pada saat akan memuat ataupun membongkar muatan. Supaya kegagalan pada pembukaan pengunci stern ramp dapat dihindari.

b. Kurangnya pengetahuan crew kapal

1) Menurut Hasil Wawancara

Dalam hal ini pemahaman crew kapal dalam pengoperasian pada saat membuka dan menutup atau mengunci pengunci pada stern ramp sangat penting. Karena banyaknya crew kapal yang belum mengetahui secara benar cara dan proses untuk membuka dan menutup atau mengunci pengunci stern ramp. Oleh karena itu Mualim I dan Masinis I perlu untuk melakukan tool box meeting kepada crew kapal terutama deck departemen. Sehingga kegagalan pada pembukaan pengunci stern ramp dapat diminimalisasi. Karena telah dilakukan sosialisasi tentang 
Dwi Antoro

bagaimana cara pengoperasian pengunci stern ramp dengan baik dan benar.

2) Metode Observasi

Dalam observasi peneliti yang melakukan penelitian pada MV. Dream Diamond. Banyak crew kapal yang kurang mengetahui dan memahami prosedur yang benar ketika melakukan pengoperasian untuk membuka dan menutup atau mengunci pengunci stern ramp. Serta masih banyak crew yang kurang mengetahui dampak yang ditimbulkan apabila pengunci stern ramp mengalami stuck.

c. Tidak dilakukannya pengecekan

1) Menurut Hasil Wawancara

Dari hasil wawancara peneliti terhadap Mualim I sebagai penanggung jawab deck departemen dan penanggung jawab proses bongkar muat dan muatan mengatakan " you should check properly if you should operating for the stern ramp locking system, check manual pin before you operate stern ramp lock system and also you check if hydraulic system can move the locking system or not" yang artinya kurang lebih yaitu, " kamu harus mengecek dengan baik jika kamu akan mengoperasikan pengunci stern ramp, cek manual pin sebelum kamu mengoperasikan pengunci stern ramp dan juga kamu cek jika hidrolik sistem dapat menggerakkan sistem penguncian atau tidak. Pengecekan terhadap pengunci stern ramp sangat lah penting, terutama pengecekan sebelum melakukan bongkar dan muat serta pengecekan selama pengoperasian pengunci stern ramp.

2) Menurut Hasil Observasi Menurut hasil observasi yang dilakukan peneliti di kapal MV. Dream Diamond selama peneliti melakukan praktek laut. Pada dasarnya crew kapal kurang memahami pentingnya melakukan pengecekan terhadap pengunci stern ramp sebelum melakukan bongkar muat dan selama pengoperasian pengunci stern ramp baik ketika membuka pengunci ataupun menutup atau mengunci. Mualim I yang bertanggung jawab penuh terhadap proses bongkar muat dan isi muatan perlu mengingtakan crew kapal dan memerintahkan crew kapal untuk melakukan pengecekan sehari sebelum melakukan bongkar muat. Serta perlunya ditempatkan dua orang crew kapal dimana salah satunya dari perwira atau masinis untuk mengecek dan mengawasi pengoperasian dari pengunci stern ramp supaya ketika pengunci stern ramp tidak dapat terbuka, dapat menginformasikan kepada bosun yang berada di control unit di sky deck. Dimana bosun selaku operator dari pengunci stern ramp dan ramp door dapat mengetahui keadaan di main deck mengenai kegagalan pengoperasian dari pengunci stern ramp sehingga tidak membuka ramp door yang menyebabkan kegagalan pada pembukaan pengunci stern ramp. Dan kemungkinan kerusakan dari pengunci stern ramp dapat dihilangkan. 


\section{Pembahasan Masalah}

Dalam pembahasan masalah peneliti mencoba untuk memberikan pemecahanpemecahan atas masalah yang terjadi di kapal MV. Dream Diamond khususnya masalah mengenai kerusakan pengunci stern ramp yang berdampak pada proses bongkar muat di suatu pelabuhan dan bagaimana mengatasi dampak-dampak yang diakibatkan kerna kerusakan dari pengunci stern ramp tersebut. Sebelumnya peneliti akan memberikan sedikit pembahasan tentang kegagalan pada pembukaan penguncistern ramp pada kapal MV. Dream Diamond agar mudah dalam memahami pembahasan masalah yang telah dirumuskan. Pengunci stern ramp adalah alat atau mesin yang berguna untuk mengunci ramp door selama dalam pelayaran, pengunci stern ramp di gerakkan dengan pompa hidrolik untuk membuka dan menutup atau mengunci. Sistem kerja pengunci stern ramp cukup sederhana, yaitu pompa hidrolik dari pengunci stern ramp akan mendorong pengunci stern ramp ke atas sehingga ramp door dapat terbuka dan setelah ramp door tertutup maka hidrolik dari pengunci stern ramp akan dioperasikan untuk bergerak turun sehingga ramp door kembali terkunci sehingga ramp door tidak akan terbuka ketika cuaca buruk.

Meskipun sistem kerja pengunci stern ramp cukup sederhana akan tetapi dampak yang ditimbulkan sangat serius, yaitu pengunci stern ramp tidak terbuka sehingga pembukaan ramp door akan tertunda dan mengakibatkan keterlambatan proses bongkar ataupun muat muatan sehingga baik perusahaan maupun pemilik muatan mengalami kerugian akibat keterlambatan proses bongkar ataupun muat tersebut. Kejadian kerusakan pengunci stern ramp terjadi ketika MV. Dream Diamond melakukan proses bongkar di pelabuhan Shanghai di Cina. Kejadian tersebut melibatkan perwira yang bertanggung jawab atas kejadian rusaknya pengunci stern ramp, terutama kepada Master dan Mualim I selaku penanggung jawab terhadap muatan.

Berikut merupakan upaya yang dilakukan untuk menanggulangi kerusakan pengunci stern ramp pada kapal MV. Dream Diamond :

1. Melakukan perawatan alat dan mesin pengunci stern ramp secara berkala untuk menunjang kelancaran pada saat proses bongkar muat.

Pengunci pada stern ramp harus mendapatkan perhatian. Karena berdasarkan fungsi utama pengunci stern ramp menunjukkan bahwa pengunci stern ramp sangat penting untuk menunjang kelancaran proses bongkar muat. Perhatian tersebut diwujudkan dengan upaya melakukan perawatan.

Perawatan sederhana yang pertamakali harus dilakukan yaitu melakukan pengecekan secara teratur. Tidak perlu setiap hari namun disesuaikan dengan perjalanan kapal menuju pelabuhan selanjutnya. Kapal dimana peneliti melakukan penelitian yaitu berjenis charterer dengan waktu tempuh berbeda beda pada setiap pelabuhan. Dengan tidak tentunya lama perjalanan kapal menuju pelabuhan selanjutnya maka Mualim I membuat keputusan melakukan perawatan ketika kapal melakukan pelayaran dengan jarak tempuh di atas 4 hari. Perawatan dilakukan pada siang hari. Perawatan dilakukan dengan memastikan tidak terdapat kebocoran pada selang hidrolik. Kemudian mencoba membuka dan mengunci ulang pengunci stern ramp tanpa membuka ramp door ketika dalam pelayaran dengan kondisi laut yang cerah gunanya untuk mengetahui fungsi dari locking system detector berfungsi atau tidak. Selain untuk mengetahui kondisi dari locking system detector membuka dan 
Dwi Antoro

menutup kembali pengunci stern ramp berfungsi untuk mengetahui kinerja dari jack hydraulic yang berfungsi membuka pengunci pada stern ramp yang terletak di sisi kanan dan kiri ramp door, apakah kedua jack hydraulic dapat membuka pengunci stern ramp secara bersamaan atau tidak. Apabila dalam pengoperasian pembukaan pengunci stern ramp terjadi keterlambatan pada salah satu sisi maka akan dilakukan perawatan terhadap selang hidrolik dengan pengecekan terhadap kondisi seal. Karena kualitas seal dapat mempengaruhi kinerja dari jack hydraulic, dimana di dalam selang hidrolik terdapat minyak pelumas yang berfungsi sebagai pelumas untuk mendorong jack hydraulic ke atas ketika mendapat tekanan yang nantinya jack hydraulic tersebut akan mendorong pengunci stern ramp sehingga menjadi unlocking position. Kemudian perawatan yang dilakukan secara berkala setiap seminggu sekali yaitu dengan jack hydraulic memberinya pelumas.

2. Melakukan pengecekan pengunci stern ramp ketika akan melakukan proses bongkar muat.

Pengecekan terhadap pengunci stern ramp biasanya dilakukan sehari sebelum sandar di pelabuhan untuk melakukan proses bongkar atau muat. Pengecekan dilakukan secara visual terhadap bagian-bagian pengunci stern ramp seperti jach hydraulic, adaptor dan fitting pada selang hidrolik. Setelah pengecekan secara visual kemudian dilakukan uji coba untuk membuka dan menutup pengunci stern ramp tanpa membuka ramp door. Uji coba dilakukan oleh bosun, klasi, deck cadet serta didampingi Mualim I. Ketika bosun melakukan pengoperasian melalui kontrol box di sky deck maka Mualim I bersama ordinary seaman dan dibantu cadet akan mengamati kerja dari pengunci stern ramp di sisi kiri dan kanan. Setelah itu Mualim I akan mencatat dan mengambil gambar dari uji coba pembukaan pengunci stern ramp untuk dijadikan laporan kepada Master. Jika terjadi kegagalan atau stuck disalah satu sisi pengunci stern ramp maka Mualim I yang berada di deck 5 akan menginformasikan kepada bosun untuk menutup kembali pengunci stern ramp dan mencoba untuk membuka kembali. Jika stuck kembali setelah dicoba berulang kali maka Mualim I akan meminta bantuan deck crew dan engine crew untuk membantu bosun memperbaiki pengunci stern ramp.

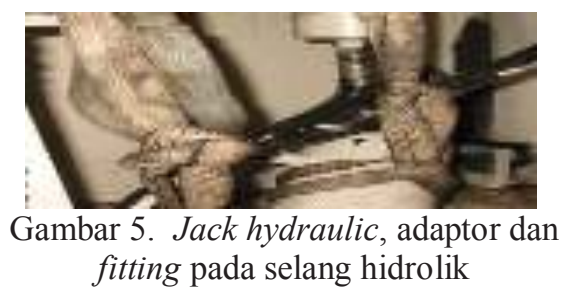

3. Cara pelaksanaan uji coba pengunci stern ramp

Pelaksaan uji coba dilakukan untuk mencegah terjadinya penundaan pelaksanaan bongkar muat ataupun hukuman dari pihak berwenang di wilayah pelabuhan tempat kapal sandar. Hal ini juga diungkapkan oleh Mualim I tentang perlunya uji coba terhadap pengunci stern ramp dalam pernyataannya sebagai berikut "One day before we arrival and berthing we should check ramp door and try to unlock the ramp door locking. If locking system in ramp door can not unlock, ramp door will can not open. It will be big problem for us" yang artinya kurang lebih "Satu hari sebelum sampai dan berlabuh kita haru mengecek ramp door dan mencoba untuk membuka pengunci ramp door. Jika pengunci ramp door tidak dapat terbuka maka ramp door 
juga tidak dapat terbuka. Itu akan menjadi masalah besar untuk kita". Cara melakukan uji pada pengunci stern ramp adalah sebagai berikut :

a. Menyalakan power untuk membuka pengunci stern ramp yang berada di steering room. Power pada steering room terdapat 2 buah power jika akan membuka pengunci stern ramp dan membuka ramp door harus 2 power.

b. Kemudian mengoperasikan untuk membuka pengunci stern ramp melalui control box atau panel yang berada di sky deck tepat di atas ramp door.

Pada panel yang berada di sky deck, pada tuas penggerak milik pengunci stern ramp terdapat 2 lampu yang bersusun tegak, apabila lampu bagian bawah telah menyala maka pengunci stern ramp berada pada posisi terkunci sedangkan apabila lampu bagian atas yang menyala maka pengunci stern ramp berada pada posisi terbuka. Akan tetapi meskipun pengunci stern ramp telah lampu indikator yang terdapat di control box, ketika dalam pengoperasian harus dilakukan pengecekan ulang dengan menanyakan pada crew kapal yang bertugas di main deck untuk mengamati pengunci stern ramp apakah kedua pengunci stern ramp (sisi kiri dan kanan) telah terbuka sepenuhnya atau belum. Karena meskipun lampu indikator pada panel telah menyala tetapi terkadang salah satu pengunci stern ramp baik sebelah kiri atau sebelah kanan terkadang masih dalam keadaan setengah terkunci. Apabila jack hydrolic tidak dapat mengangkat salah satu dari kedua pengunci stern ramp dengan sempurna maka ramp door tidak akan dapat terbuka.
Setelah melakukan uji pembukaan pengunci stern ramp maka Mualim I akan mencatat hasil dan melaporkan hasil tersebut kepada Master sebagai bahan pertimbangan. Hasil dari laporan kemudian akan didiskusikan atau dibahas bersama Mualim I, dan apabila terdapat kendala maka akan meminta pertimbangan dari kepala kamar mesin dan juga perwira kamar mesin.

Apabila terjadi kerusakan ketika dalam perjalanan menuju pelabuhan tujuan maka akan dilakukan segala cara agar pengunci stern ramp dapat terbuka. Hal ini dilakukan karena proses bongkar di Shanghai tidak memakan waktu sampai 5 jam sehingga tidak memungkinkan untuk melakukan perbaikan dan juga terdapat larangan untuk melakukan perbaikan di area muatan ketika kapal sedang melakukan proses bongkar ataupun muat selain itu juga guna menghindari adanya hukuman dari pihak berwenang. Apabila tidak terjadi kerusakan maka Mualim I akan melaporkan kepada Master yang akan diteruskan kepada perusahaan bahwa kondisi pengunci stern ramp dalam keadaan bagus dan layak digunakan.

4. Memberikan pengarahan terhadap crew kapal tentang pengoperasian pengunci stern ramp sesuai dengan prosedur yang benar.

Pemberian pengarahan terhadap crew kapal mengenai pengoperasian pengunci stern ramp dilakukan oleh Master atau Mualim I dan dibantu oleh kepala kamar mesin serta Masinis I, pemberian pengarahan dilakukan dengan mengadakan tool box meeting atau safety meeting terutama terhadap deck crew. Memberikan pengarahan terhadap crew kapal tentang pengoperasian ketika membuka dan mengunci pengunci stern ramp bertujuan agar 
Dwi Antoro

seluruh awak kapal dapat melakukan pengoperasian pengunci stern ramp dengan baik dan benar sesuai dengan prosedur yang ada. Dan mengetahui tindakan yang tepat ketika terjadi kerusakan atau stuck pada saat pengoperasian pengunci stern ramp. Pemberian pengarahan dilakukan karena mengingat dampak yang ditimbulkan jika terjadi kegagalan pada pembukaan penguncistern ramp

\section{KESIMPULAN}

Berdasarkan uraian dari permasalahan tentang kerusakan pengunci stern ramp pada MV. Dream Diamond, maka sebagai bagian akhir dari penelitian ini, peneliti akan mencoba memberikan beberapa kesimpulan dan saran yang berkaitan dengan masalah yang dibahas dalam penelitian ini yaitu :

1. Penyebab-penyebab terjadinya kerusakan pengunci stern ramp pada MV. Dream Diamond adalah :

a. Kurangnya pengetahuan crew kapal mengenai pengunci stern ramp;

b. Kurangnya komunikasi pada saat pengoperasian;

c. Pengoperasian pada saat membuka atau menutup pengunci stern ramp tidak sesuai dengan prosedur yang ada;

d. Tidak dilakukan pengecekan sebelum pengoperasian;

e. Tidak dilakukannya perawatan secara berkala pada pengunci stern ramp;

f. Temperatur suhu lingkungan yang rendah.

Dengan penyebab masalah utama yaitu karena tidak dilakukannya pengecekan sebelum pengoperasian.

2. Terjadinya kerusakan pengunci stern ramp yang terjadi di kapal MV. Dream Diamond mengakibatkan kapal mengalami keterlambatan pada saat proses bongkar. Perusahaan kapal serta pencarter dapat mengalami kerugian dan hukuman dari pihak pelabuhan baik kerugian waktu ataupun kerugian materi akibat keterlambatan proses bongkar muat tersebut. Bahkan kapal dapat menerima peringatan atau hukuman dari pihak pelabuhan yang berkaitan dengan kelangsungan pada saat proses bongkar muat yang tidak sesuai dengan yang direncanakan. Dan kapal dapat diblacklist dari pelabuhan tersebut karena kapal tidak memenuhi syarat yang baik dan benar untuk melaksanakan bongkar muat.

Adapun saran-saran pemecahan masalah yang didapat adalah sebagai berikut :

1. Mengantisipasi kegagalan pembukaan pengunci stern ramp yang terjadi dengan meningkatkan pengecekan terhadap pengunci stern ramp sebelum mengoperasikannya dan melakukan perawatan berkala dengan baik serta tepat waktu terhadap pengunci stern ramp. Segera lakukan perbaikan apabila terdapat kerusakan pada saat pengecekan pada pengunci stern ramp.

2. Berikan education kepada crew kapal terutama crew baru ataupun crew yang pertamakali bekerja di kapal dengan tipe kapal Ro-Ro tentang bagaimana mengoperasikan pengunci stern ramp dan ramp door dengan baik dan benar agar terhindar dari bahaya kerusakan atau kegagalan pembukaan pengunci stern ramp yang dapat menyebabkan keterlambatan dalm proses bongkar ataupun muat.

\section{DAFTAR PUSTAKA}

Sudjatmiko. 2013. Pokok-Pokok Pelayaran Niaga. Jakarta

Jokosiswoyo, S. 2011. Analisis Fatigue Kekuatan Stren Ramp Door Akibat Beban Dinamis Pada KM. KiranaI Dengan Metodo Elemen Hingga Diskrit Elemen Segitiga 
Jurnal Dinamika Bahari Vol. 9 No. 1 Edisi Oktober 2018

Sugiyono. 2015. Metode Penelitian Pendidikan. Bandung

MacGregor book guide book for Stern Ramp Door , http://www.macgregor.com 